\title{
Trichodina sp. (Ciliophora: Peritrichida) in eel Anguilla anguilla in recirculation systems in Denmark: host-parasite relations
}

\author{
Hans C. K. Madsen ${ }^{1}$, Kurt Buchmann ${ }^{2}$, Stig Mellergaard ${ }^{1, *}$ \\ ${ }^{1}$ Danish Institute for Fisheries Research, Department of Marine Ecology and Aquaculture, Fish Diseases Laboratory, \\ 1870 Frederiksberg C, Denmark \\ ${ }^{2}$ Royal Veterinary and Agricultural University, Section of Fish Diseases, 1870 Frederiksberg C, Denmark
}

\begin{abstract}
Farmed eel cultured in recirculation systems in Denmark were found infected by Trichodina jadranica Raabe, 1958. Associations between parasite abundance and fish size was examined in 2 different production systems. In one system, stocked with relatively well-nourished eels ( 3 to $31 \mathrm{~g}$ ), most of the parasites $(66 \%)$ were found on the dorsal part on the skin and relatively few were found on the gills (approx. $8 \%$ ). The infection level was significantly positively correlated both with fish weight and length. In the other system, stocked with relatively malnourished small eels (0.5 to $4 \mathrm{~g}$ ), significantly more parasites $(0.06 \pm 0.02[\mathrm{SD}])$ were present on fish with a low condition factor than on fish with a higher condition factor $(0.13 \pm 0.01[\mathrm{SD}])$. In this eel stock the vast majority of the trichodines were found on the gills.
\end{abstract}

KEY WORDS: Eel - Trichodiniasis - Host-parasite relation · Recirculation system $\cdot$ Growth inhibition

Resale or republication not permitted without written consent of the publisher

Production of eel Anguilla anguilla L. in recirculation systems in Denmark is based on imported glass eels or elvers caught in river estuaries along the European Atlantic coast. Among the parasites introduced to the farms together with the imported eels is Trichodina sp. (Mellergaard \& Dalsgaard 1987), which inhabits the skin and the gills. In the wild, trichodines live externally on fishes with no clinical effects. However, under certain conditions such as intensive aquaculture these ciliates may proliferate massively and have been reported to cause pathology in fish (Bauer et al. 1973, Schäperclaus 1979, Mellergaard \& Dalsgaard 1987, Lom \& Dyková 1992, Buchmann \& Bresciani 1997). This study deals with the following aspects of the relations between the eel and Trichodina jadranica: the pathogenity of the ciliate dependent of the condition of the host, the microhabitat on eel and the habitat in eel farms.

*Corresponding author. E-mail: sme@dfu.min.dk
Materials and methods. In order to identify the trichodinids, specimens were collected from eels at 11 different eel farms during a 19 mo period (in 1997 and 1998) and from glass eels or elvers imported from France to Denmark in April 1998. The eels were killed, fixed with needles and as many as possible of the trichodines were collected by scraping mucus from skin and gills (removed from fish) with a scalpel from 1 side of the still moistened eel and transferred to glass slides. The specimens were air dried, impregnated with a $2 \%$ silver nitrate solution for $40 \mathrm{~min}$ and exposed to ultraviolet radiation for $30 \mathrm{~min}$. Diameters of the adhesive disc and the ring of the denticles, the number of denticles and the number of radial pins per denticle (see Lom \& Dyková 1992) were examined microscopically. The results and photographs were compared to results from other studies.

The number of trichodines per fish in relation to fish size were studied in 2 different eel stocks. The eels in Stock 1 (Table 1) were relatively well-nourished and this stock was assumed to be representative of the general condition of eels under farm conditions. In Stock 1, the total number of parasites per fish (the number of trichodines from skin and gills was pooled) $(\mathrm{n}=98)$ was correlated with fish length, weight and condition factor (weight $[\mathrm{g}] \times 100 \times$ length $\left[\mathrm{cm}^{-3}\right.$ ) using Spearman's rank correlation test. Furthermore, the microhabitats of trichodines on eels $(n=20)$ in Stock 1 were examined (gills, head, dorsal body [including dorsal fin] and ventral body [including anal fin]). Another stock of eels, Stock 2, with relatively old (6 to $12 \mathrm{mo}$ ) but small fish, discards from several size gradings, were examined. This stock was comprised of 2 distinctive types of eels. Type A ( $\mathrm{n}=40)$ was a well-nourished eel and Type B $(\mathrm{n}=40)$ a malnourished eel (Table 1). Due to an extremely high parasite burden, the infection level (the number of trichodines on gills and skin, respectively) 
Table 1. Data on infected (trichodinids) eels examined for host-parasite relations. Stock 1: Relatively well-nourished eels - representative of eel condition in most production systems. Stock 2: Relatively many eels were in a bad condition; 2 distinctive types (A and B) of eels were seen

\begin{tabular}{|lcccc|}
\hline & \multicolumn{2}{c}{ Stock 1 } & \multicolumn{2}{c|}{ Stock 2 } \\
& Mean ( \pm SD) & Range & Type A & Type B \\
& & & Mean $( \pm$ SD) & Mean $( \pm$ SD) \\
\hline Weight $(\mathrm{g})$ & $7(5)$ & $3-31$ & $2.2(0.6)$ & $1.0(0.5)$ \\
Length $(\mathrm{cm})$ & $17(3)$ & $12-24$ & $11.8(0.9)$ & $11.6(1.5)$ \\
Condition factor & $0.13(0.02)$ & $0.07-0.20$ & $0.13(0.01)$ & $0.06(0.02)$ \\
& & & & \\
\hline
\end{tabular}

of eel host. Some variation in size between different ecotypes of the same species of trichodines is possible (Schäperclaus 1979), and we assume the trichodines on the examined glass eels and farmed eels to belong to the same species, T. jadranica.

Growth inhibition is probably the most common effect caused by trichodiniasis (Sanmartin et al. 1991, Lom \& Dyková 1992). We examined host-parasite relations in 2 eel stocks with different characteristics defined by conditon. In the eel

was converted into 4 categories: $0=0$ parasites $(\mathrm{p}) ; 1=$ 1 to $10 \mathrm{p} ; 2=11$ to $100 \mathrm{p} ; 3=100$ to $1000 \mathrm{p}$. The categories for Types A and B were compared using the Mann-Whitney $U$-test (2-tailed).

The location of the trichodines were studied in a recirculation unit (total volume: $90 \mathrm{~m}^{3}$, no strainer facilities between tanks and biofilters) stocked with approximately $5 \mathrm{t}$ of eels ( 2 to $50 \mathrm{~g}$ ) heavily infested with trichodine (approx. 50 to 400 parasites fish $^{-1}$ ). Water samples $(2 \times 51)$ and samples of the biofilm from the tank wall (approx. $50 \mathrm{~cm}^{2}$ at a depth of a few $\mathrm{mm}$, 5 replicates) were taken from both fish tanks and biofilter. The samples were gently filtrated through a cellulose membrane with a pore size of $30 \mu \mathrm{m}$ (e.g. smaller than the diameter of Trichodina jadranica). A few $\mathrm{ml}$ before total filtration the contents was transferred to petri dishes and were examined for the presence of trichodines either free swimming or attached to invertebrates (ciliates, rotifers, copepods, nematodes, turbellarians, oligochaetes and ostracods). In addition, the time of survival of the trichodines separated from the host was examined by following the survival in petri dishes containing farm water $\left(25^{\circ} \mathrm{C}\right)$.

Results and discussion. Trichodina sp. was described as being responsible for disease problems in eel Anguilla anguilla in recirculation aquaculture in Denmark in the 1980s (Mellergaard \& Dalsgaard 1987). Later samples of trichodines were identified as T. jadranica (Lyholt \& Buchmann 1995). In the present work all collected trichodines from skin and gills on cultivated eels had a relatively similar body size and a uniformly shaped denticle (thorn, central part and blade) all conforming to the $T$. jadranica specific characters (Fig. 1). The examined morphometric characteristics varied within the ranges given in Table 2 . Monocultures of the observed trichodines seem to be the only agent causing trichodiniasis in eel farms in Denmark. The trichodines on newly imported glass eels from France tended to be slightly smaller than the trichodines on farmed eels. However, no difference in the shape of the elements in the skeleton was observed between the specimens found on the 2 types stock representing eels in a relatively good condition we found that the number of trichodines per fish was positively correlated with fish weight $(\mathrm{r}=0.33, \mathrm{p}<$ $0.001)$ and with length $(\mathrm{r}=0.35, \mathrm{p}<0.001)$ but not with the condition factor $(r=0.12, p<0.22)$. Most of the parasites were found on the skin (dorsal body, 66\%; ventral body, 21\%; head, 5\%; gills, 8\%) (Fig. 2). Under these conditions, the infection level seemed to be dependent on the surface available as substrate. No direct pathogenic effect of the trichodines was observed.

In the relatively malnourished eels the vast majority of the parasites were located on the gills (Fig. 3). In this eel stock association between low fish condition and high infection level was observed. Type B eels (condition factor, $0.06 \pm 0.02$ [SD]) harboured significantly $(\mathrm{p}<0.001)$ more parasites in the gills than Type A eels, which had a higher condition factor $(0.13 \pm$ 0.01 [SD]). No difference in the parasite burden on

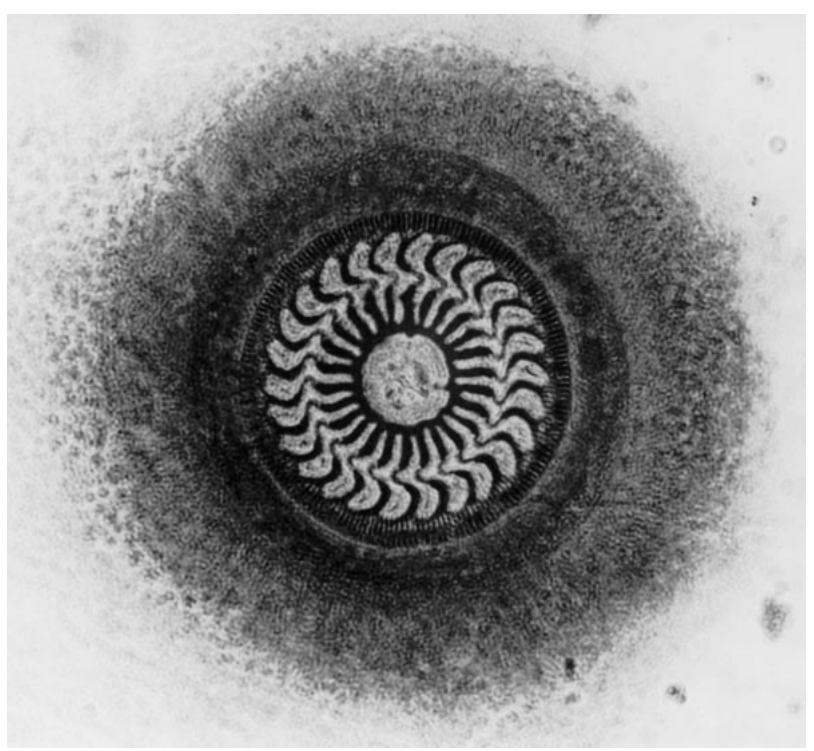

Fig. 1. Trichodina jadranica found on cultivated eel Anguilla anguilla in Denmark. Ring of denticles: $24 \mu \mathrm{m}$ 
Table 2. Data on size and denticles (mean $[ \pm \mathrm{SD}]$, range) of Trichodina found in present work and data on T. jadranica given in literature

\begin{tabular}{|c|c|c|c|c|c|c|c|}
\hline Trichodina & $\begin{array}{l}\text { Eel farm, } \\
\text { Denmark }\end{array}$ & $\begin{array}{l}\text { Eel farm, } \\
\text { Denmark }\end{array}$ & $\begin{array}{l}\text { Adriatic } \\
\text { Sea }\end{array}$ & $\begin{array}{l}\text { Mexican } \\
\text { Gulf }\end{array}$ & $\begin{array}{l}\text { Black } \\
\text { Sea }\end{array}$ & $\begin{array}{l}\text { Eel farm, } \\
\text { Japan }\end{array}$ & $\begin{array}{l}\text { The Atlantic, } \\
\text { Senegal }\end{array}$ \\
\hline \multicolumn{8}{|l|}{ Diameter ( $\mu \mathrm{m})$} \\
\hline Adhesive disc & $34(3.1), 29-40$ & $37(4.1), 31-41$ & $28-38$ & $25(2.7), 20-31$ & $20-27$ & $32(3.7), 30-35$ & $31(2.5), 27-36$ \\
\hline Ring of denticles & $21(1.9), 19-28$ & $23(2.8), 19-29$ & $16-22$ & $14(1.7), 11-18$ & $13-16$ & $18(2.1), 16-20$ & $18(1.8), 16-22$ \\
\hline \multicolumn{8}{|l|}{ Number } \\
\hline Denticles & $26(1.6), 24-28$ & $26(0.9), 24-27$ & & $19(1.2), 17-22$ & $19-21$ & $23(0.7), 22-25$ & $18,17-20$ \\
\hline Pins per denticle & $6-8$ & $6-8$ & 8 & $5-7$ & 6 & $7-8$ & $9,8-9$ \\
\hline $\mathrm{n}$ & 30 & 10 & & 25 & 3 & 10 & 12 \\
\hline Microhabitat & Skin & Gills & Gills & Gills & Gills & Gills & $?$ \\
\hline Species & $\begin{array}{l}\text { Anguilla } \\
\text { anguilla }\end{array}$ & $\begin{array}{l}\text { Anguilla } \\
\text { anguilla }\end{array}$ & $\begin{array}{l}\text { Mullus } \\
\text { barbatus }\end{array}$ & $\begin{array}{c}\text { Citharichthys } \\
\text { spilopterus }\end{array}$ & $\begin{array}{c}\text { Crenilabrus } \\
\text { ocellatus } \\
\text { + more }\end{array}$ & $\begin{array}{c}\text { Anguilla } \\
\text { japonicum }\end{array}$ & $\begin{array}{l}\text { Balistes } \\
\text { punctatus }\end{array}$ \\
\hline Source & $\begin{array}{l}\text { This study } \\
\text { (1998) }\end{array}$ & $\begin{array}{l}\text { This study } \\
\text { (1998) }\end{array}$ & $\begin{array}{l}\text { Raabe } \\
(1958)\end{array}$ & $\begin{array}{l}\text { Arthur \& Lom } \\
\quad(1984)\end{array}$ & $\begin{array}{c}\text { Grupcheva et al. } \\
\text { (1989) }\end{array}$ & $\begin{array}{l}\text { Soichi et al. } \\
\text { (1991) }\end{array}$ & $\begin{array}{l}\text { Jaco et al. } \\
\text { (1995) }\end{array}$ \\
\hline
\end{tabular}

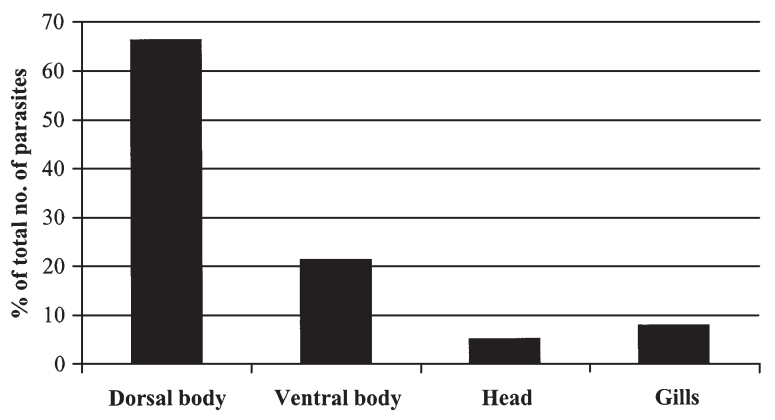

Fig. 2. Trichodina jadranica microhabitat choice on the eel Anguilla anguilla (Stock 1)
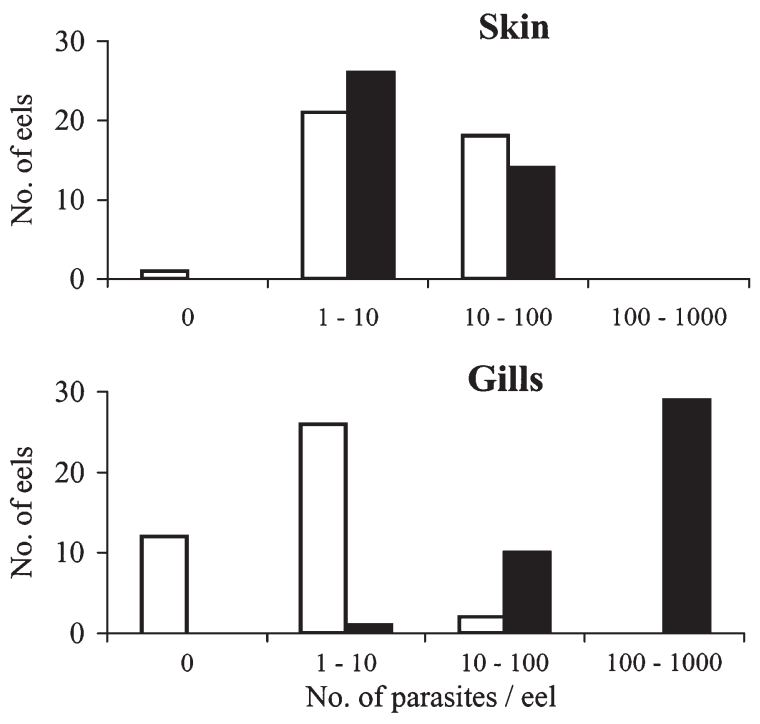

$\square$ Condition factor 0.13

Condition factor 0.06

Fig. 3. Trichodina jadranica inhabiting Anguilla anguilla. Presence of trichodines on the skin and gills of Stock 2 Type A $($ condition factor $=0.13)$ and Type $\mathrm{B}($ condition factor $=0.06)$ eels the skin between the 2 eel types was found. Under these circumstances the possibility cannot be excluded that the trichodines were serious pathogens causing growth inhibition of the host. Severe pathogenicity caused by trichodines resulting in mortality has been observed under controlled experiments in other studies (Subasinghe 1993, Obiekezie \& Ekanem 1995). However, the possibility cannot be excluded that the eels in the present situation were stressed by other factors which increased their susceptibility to infection and that the gills of these fish were a better habitat than the skin. In the recirculation system stocked with heavily infected eels, the tank water contained 1 to 5 free-swimming trichodines per $5 \mathrm{l}$ of water. No trichodines were found in the biofilters or in the biofilm of the rearing tanks. In the absence of a host, the trichodines survived for at most $16 \mathrm{~h}$ in petri dishes. Apparently, the trichodines lived on and in the vicinity of the eel, and only left their host temporarily to search for new potential fish hosts. The biofilters did not seem to be a suitable habitat. Formerly, Trichodina sp. have been found on zooplankton (Basson \& Van As 1991), but in this study $T$. jadranica did not seem to extend its infection to invertebrate hosts, which therefore did not function as a reservoir for the parasite in recirculation eel farms.

Acknowledgements. We are indebted to the owners and staff on Steensgaard Eel Farm, Randboel, and Dyrkjaerslund Eel Farm, Baelum, Denmark, for assistance as well to Dr J. Bresciani, Section of Zoology, Royal Veterinary and Agricultural University, Copenhagen, for assistance with parasite identification. The work was funded by the Danish Directorate for Development of Aquaculture and Fisheries and the Elisabeth and Knud Petersen Foundation. 


\section{LITERATURE CITED}

Arthur JR, Lom J (1984) Some trichodinid ciliates (Protozoa: Peritrichida) from Cuban fishes, with a description of Trichodina cubanensis n.sp. from the skin of Cichlasoma tetracantha. Trans Am Microsc Soc 103:172-184

Basson L, van As JG (1991) Trichodinids (Ciliophora: Peritrichida) from a calanoid copepod and catfish from South Africa with notes on host specificity. Syst Parasitol 18: $147-158$

Bauer ON, Musselius VA, Strelkov YuA (1973) Diseases of pond fishes. Israel Program for Scientific Translations Ltd, Jerusalem, p 78-82

Buchmann K, Bresciani J (1997) Parasitic infections in pondreared rainbow trout Oncorhynchus mykiss in Denmark. Dis Aquat Org 28:125-138

Grupcheva G, Lom J, Dyková I (1989) Trichodinids (Ciliata: Urceolariidae) from the gills of some marine fishes with the description of Trichodina zaikai sp.n. Folia Parasitol 36:193-207

Jaco G, Loubser J, van As JG, Basson L (1995) Trichodinid ectoparasites (Ciliophora: Peritrichida) of some fishes from the Bay of Dakar, Senegal (West Africa). Acta Protozool 34:211-216

Lom J, Dyková I (1992) Protozoan parasites of fishes. Elsevier Science Publishers BV, Amsterdam, p 237-288

Lyholt HCK, Buchmann K (1995) Infestations with the skin

Editorial responsibility: Wolfgang Körting,

Hannover, Germany parasite Trichodina jadranica Raabe, 1958 (Ciliophora: Trichodinidae) in Danish eel farms. Bull Scand Soc Parasitol 5:97

Mellergaard S, Dalsgaard I (1987) Disease problems in Danish eel farms. Aquaculture 67:139-146

Obiekezie A, Ekanem D (1995) Experimental infection of Heterobranchus longifilis (Teleostei, Clariidae) with Trichodina maritinkae (Ciliophora, Peritrichida). Aquat Living Resour 8:439-443

Raabe Z (1958) On some species of Trichodina (Ciliata-Peritrichida) of the gill of Adriatic fishes. Acta Parasitol Pol 6:355-361

Sanmartin DML, Fernandez CJ, Tojo JL, Santamarina MT, Estevez J, Ubeira F (1991) Trichodina sp.: effect on the growth of farmed turbot (Scophthalmus maximus). Bull Eur Assoc Fish Pathol 11:89-91

Schäperclaus W (1979) Protozoosen. In: Schäperclaus W (ed) Fischkrankheiten, 4th edn. Akademie Verlag, Berlin, p 538-632

Soichi I, Hiroyasu M, Kiohiko N (1991) Trichodinid species from the gill of cultured Japanese eel, Anguilla japonicum, with the description of the new species based on light and scanning electron microscopy. Eur J Protistol 27:79-84

Subasinghe RP (1993) Effects of controlled infections of Trichodina sp. on transmission of epizootic ulcerative syndrome (EUS) to naive snakehead, Ophicephalus striatus Bloch. J Fish Dis 16:161-164

Submitted: February 9, 2000; Accepted: May 22, 2000 Proofs received from author(s): August 4, 2000 